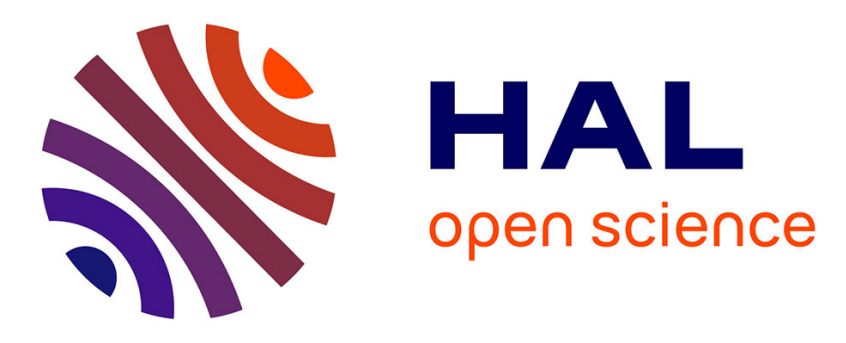

\title{
3D Global Windings Hybrid Excitation Switching Flux machine
}

Emmanuel Hoang, Agathe Dupas, Sami Hlioui, Michel Lécrivain, Mohamed

Gabsi

\section{- To cite this version:}

Emmanuel Hoang, Agathe Dupas, Sami Hlioui, Michel Lécrivain, Mohamed Gabsi. 3D Global Windings Hybrid Excitation Switching Flux machine. 17th International Conference on Electrical Machines and Systems (ICEMS2014), Oct 2014, Hangzhou, China. hal-01077691

\section{HAL Id: hal-01077691 \\ https://hal.science/hal-01077691}

Submitted on 27 Oct 2014

HAL is a multi-disciplinary open access archive for the deposit and dissemination of scientific research documents, whether they are published or not. The documents may come from teaching and research institutions in France or abroad, or from public or private research centers.
L'archive ouverte pluridisciplinaire HAL, est destinée au dépôt et à la diffusion de documents scientifiques de niveau recherche, publiés ou non, émanant des établissements d'enseignement et de recherche français ou étrangers, des laboratoires publics ou privés. 


\title{
3D Global Windings Hybrid Excitation Switching Flux machine
}

\author{
E. Hoang ${ }^{1}$, A. Dupas ${ }^{1}$, S. Hlioui ${ }^{2}$, M. Lecrivain ${ }^{2}$, M. Gabsi ${ }^{1}$ \\ ${ }^{1}$ SATIE, ENS Cachan, CNRS, UniverSud, 61, av Président Wilson, F-94230 Cachan, France \\ ${ }^{2}$ SATIE, CNAM, CNRS, ENS Cachan \\ E-mail: hoang@satie.ens-cachan.fr
}

\begin{abstract}
In this paper a new structure of a hybrid excitation flux-switching synchronous machine is presented. A 3D finite elements analysis and a comparison with experimental results are exposed. This model makes possible to show the flux path of the excitation flux and to explore the flux regulation capability of this new structure. The on-load performances of this machine, in DC generator, are also analyzed.
\end{abstract}

\section{INTRODUCTION}

Hybrid excitation machines combines advantages of wound excitation machines and permanent-magnet excited machines. Electric excitation offers a control of the magnetic field by controlling the excitation current while permanent magnet benefits from a high-energy density.

Many hybrid excited topologies were proposed in the literature and compared with PM machines. One of these topologies is the hybrid flux-switching machine presented in [1]-[4]. Due to a salient passive rotor, hybrid excited flux-switching permanent magnet machines have high robustness and thanks to permanent magnets localized on the stator the machine have high torque density.

In this study, a new hybrid excitation flux-switching machine is presented. The main characteristic of this machine is a global winding hybrid excitation.

In this paper we will, firstly, present the structure and the operation principles of this new hybrid excitation fluxswitching machine. Secondly, a 3D Finite Element model and the influence of DC Excitation Current on the no-load flux and on the short-circuit current will be presented. In order to validate the principle of operation of this new structure and the 3D FE analyses, a prototype machine was manufactured. The no-load and on-load tests of this machine will be presented.

\section{Presentation OF The STRUCTURE}

\section{A. Topology}

This machine is composed of a stator that includes armature coils, permanent magnets and a wound inductor (with global windings). The rotor is simply made of salient poles.

In our first version of the hybrid excited flux-switching machine [1]-[2], the magnetic structure has axial symmetry, this is a 2D structure. The excitation windings are composed of 12 windings and are located upon the permanent magnets. The new structure, presented in this paper, is has a global DC excitation windings. Figure 1 shows a $3 \mathrm{D}$ view of the proposed 12 slots and 10 poles machine.
The wounded excitation part is composed by the excitation winding and two armatures that are made, in the first prototype, by solid iron materials.

We study the possibility to manufacture them by soft magnetic composites (SMC).

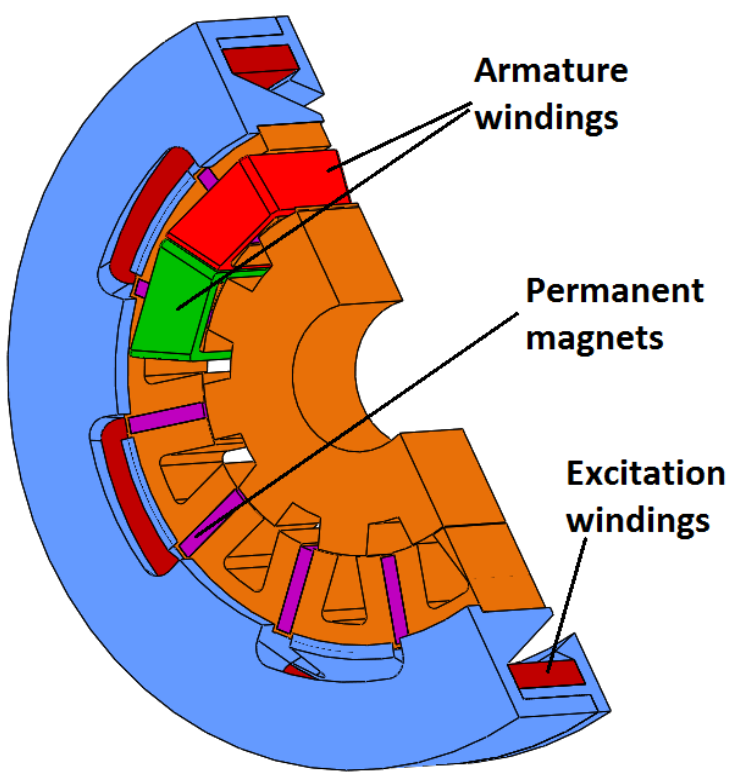

Figure 1: 3D view of the machine

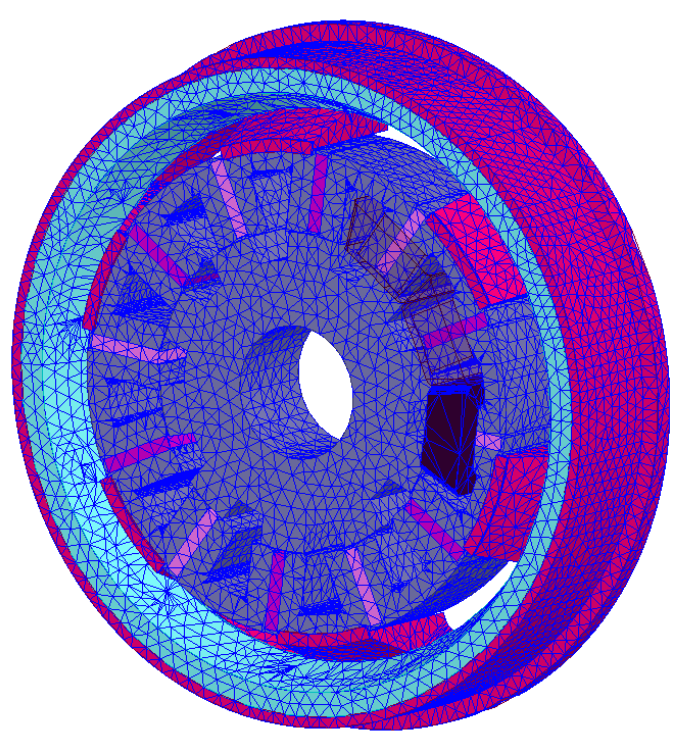

Figure 2: 3D view of the machine mesh

\section{B. Operation Principles}

In this part, the operating principle of this new structure is presented. The flux density distributions in the prototype 
machine under different excitation currents are presented. On figure 3 , we present the value of the amplitude of the no-load flux for different values of excitation current. Like the first version, we show the effectiveness of flow control with this new realization of the excitation circuit.

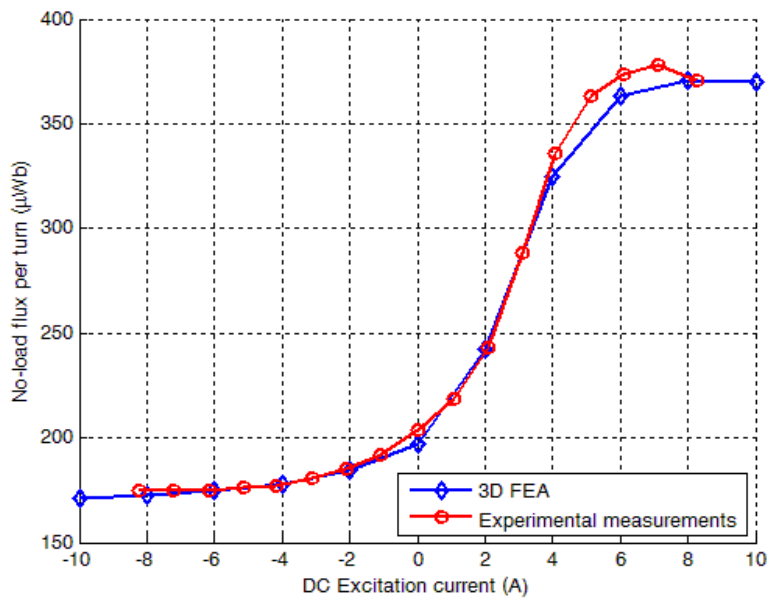

Figure 3: Maximum no-load flux versus excitation current. Comparison between 3D FE model and experimental results.

The second intrinsic characteristic of the machine is the value of the short-circuit current. In Figure 4, we present the evolution of these short-circuit current depending on the hybrid excitation current. We added the values of the thermal currents. To determine theses values, we applied a direct current as the resistance value increases by $40 \%$.

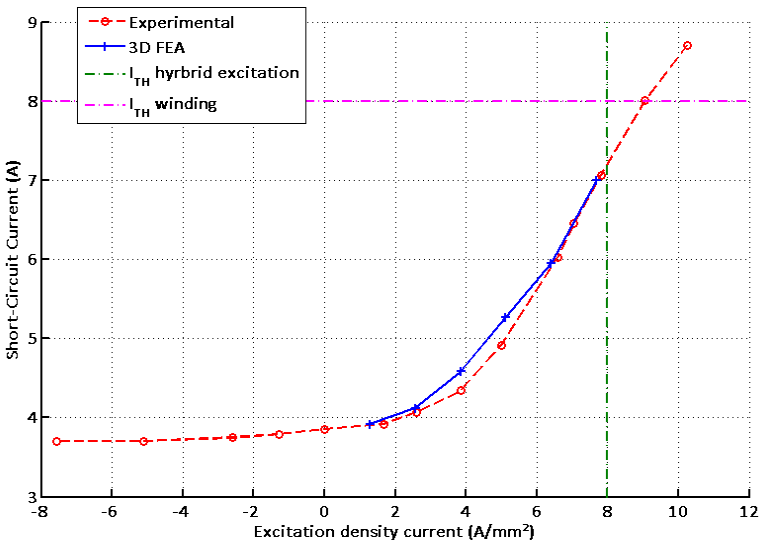

Figure 4: Short-circuit current versus excitation current. Comparison between 3D FE model and experimental results.

\section{3D FE ANALYSIS}

The magnetic field is computed by using 3D FEA. Noload flux and machine in motor mode are explored.

We can see in Figure 5 and Figure 6 the values of the flux density and the local saturation. It should be noted that the outer ring was made of steel for the prototype and this is what justifies the above 2 Tesla in the excitation circuit values. We are conducting a study of analytical modeling and optimization of the shape and constitution of this new excitation circuit study.

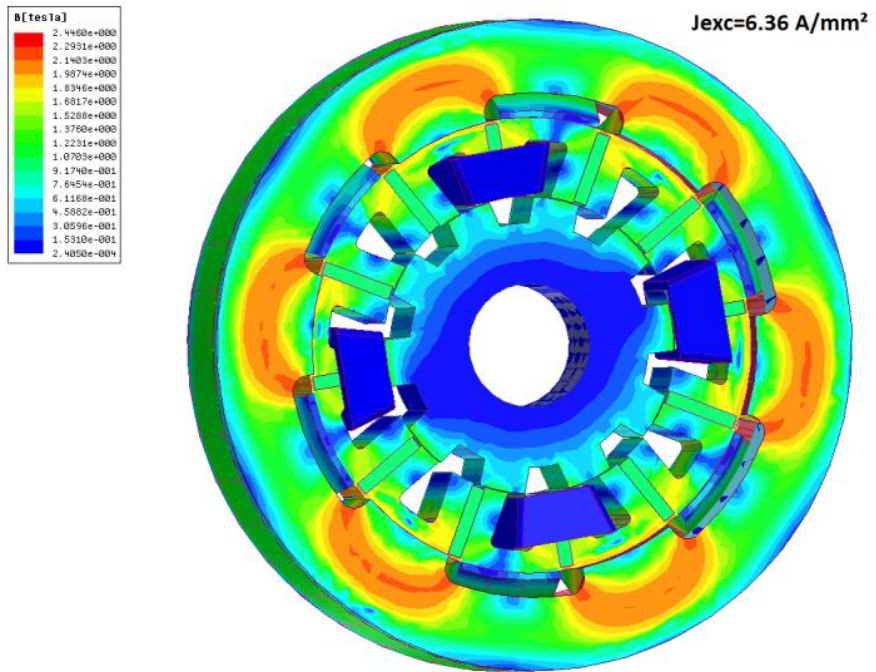

Figure 5: 3D FE analysis. Flux density map.

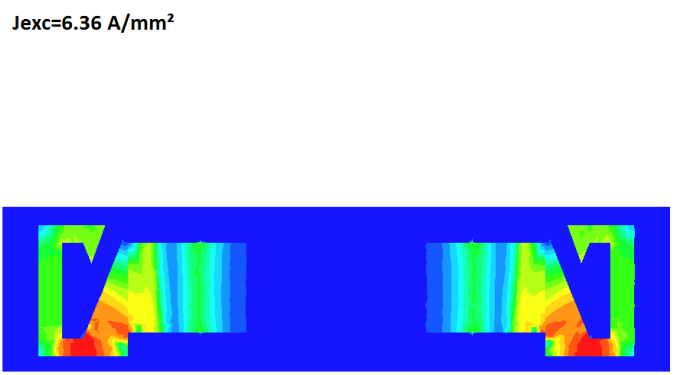

Figure 6: 3D FE analysis. Flux density map.

\section{PRototype VALIDATION}

In order to validate the operating principle of this new structure a prototype is realized. The experimental results for no-load and on-load tests will be presented. In Figure 3, we introduced the no-load flux and the short-circuit current in Figure 4.

In order to test the performance of this new machine, we conducted tests in DC generator mode. The experimental test bench is shown in Figure 7 [4].

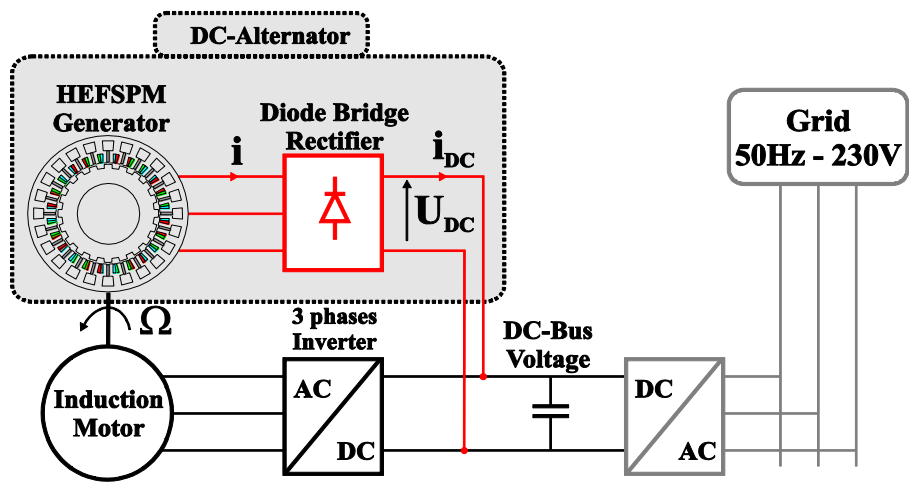

Figure 7: Experimental test bench [4].

The tests were carried out with a value of the DC bus voltage of $300 \mathrm{~V}$. We find the characteristic curve of a synchronous machine coupled to a diode rectifier (see figure 8). We show the values of the various losses that we could measure. Copper losses in armature and excitation circuits are determined with the values of resistors and 
currents. We measure the torque with a balance assembly. We deduce the value of the mechanical power. Measuring the output power is knowing with the value of the continuous current output. The sum of the mechanical losses and iron losses is made by taking the difference between the mechanical power and the copper losses and the DC side power.

We are currently studying the models of iron losses and mechanical losses to distinguish them.

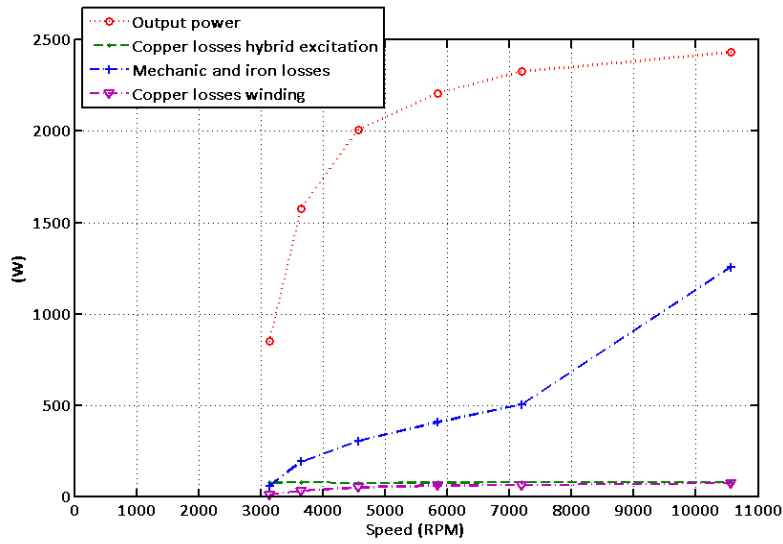

Figure 8: Experimental results in DC generator mode under $300 \mathrm{~V}_{\mathrm{DC}}$.

\section{COMPARATIVE STUDY OF THE TWO STRUCTURES OF THE EXCITATION CIRCUIT}

\section{A. Description of the structure}

In our first version of the hybrid excited flux-switching machine, the magnetic structure has axial symmetry. This is a 2D machine as most electrical machines. We can see from the picture shown in the following figure one of the disadvantages of these machines with axial symmetry is what is called the" heads" coils, especially if the length of the laminations is low.

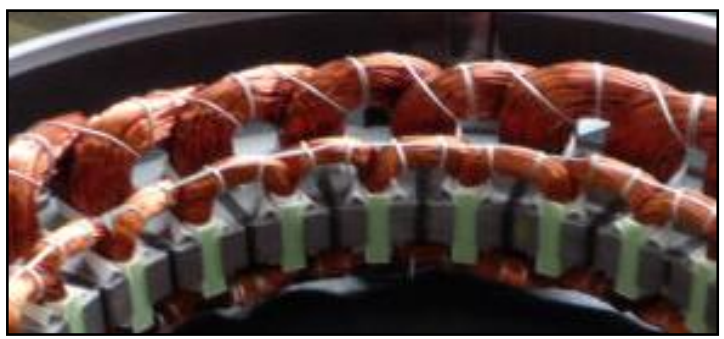

Figure 9: View of the two winding.

In this paper we present a new arrangement of the excitation coil, one that is driven by a DC current. In Figure 10 , we present the original configuration, where all the conductors are perpendicular to the magnetic circuit, and wherein the windings are cellular, that is to say that they are entirely made in one unit cell.

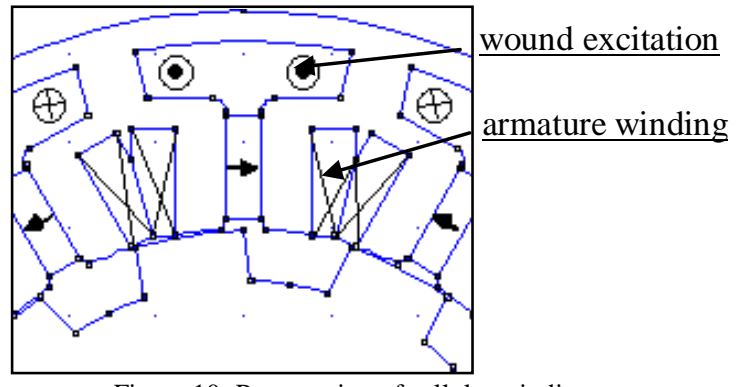

Figure 10: Presentation of cellular windings.

The excitation coil is associated with a magnetic circuit, driven primarily by a continuous flow, as indicated by red arrows in the photo below.

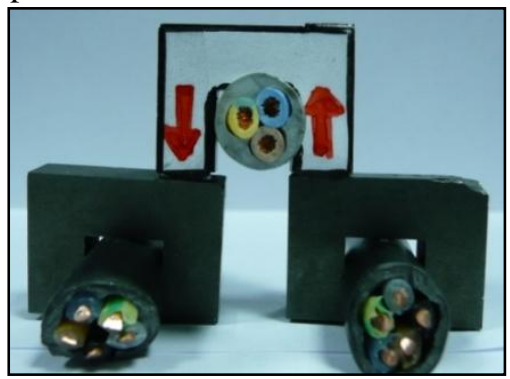

Figure 11: Front view of the excitation circuit.

The principle is to" turn" by $90^{\circ}$ the excitation circuit as shown in the following two pictures.

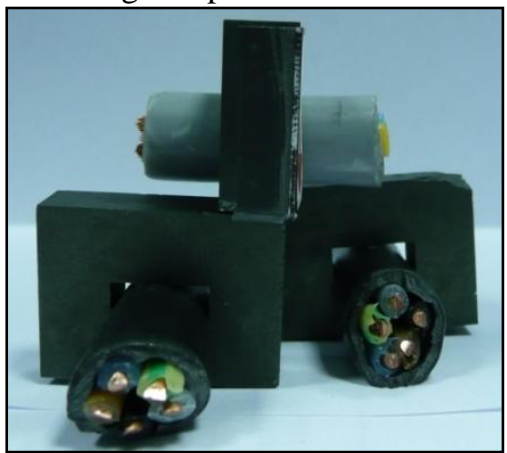

Figure 12: Front view with excitation circuit rotated by $90^{\circ}$.

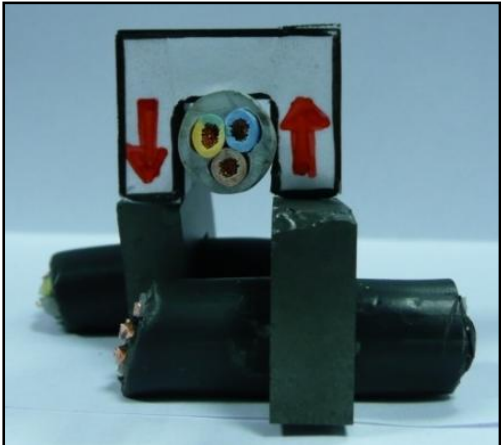

Figure 12: Side view with excitation circuit rotated by $90^{\circ}$.

As we can see from the previous pictures, the magnetic excitation circuit will need to be modified so that it can achieve a" bridge" magnetic while the magnetic circuit of the armature remains unchanged, as shown in next figures. 


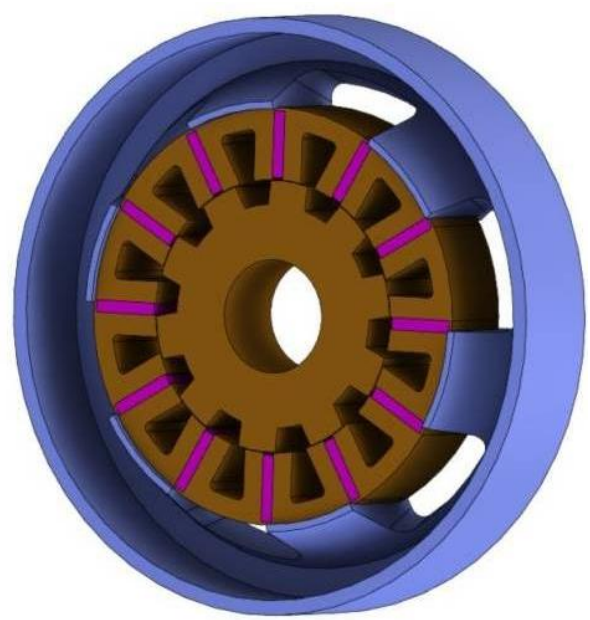

Figure 13: Description of half the excitation circuit.

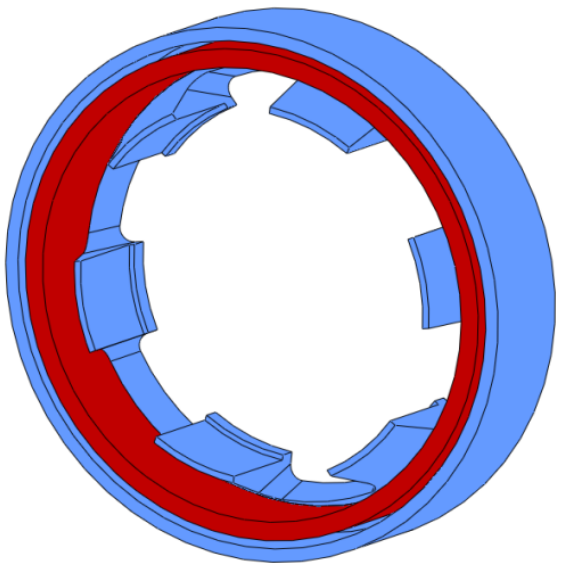

Figure 14: Description of half the excitation circuit with the winding.

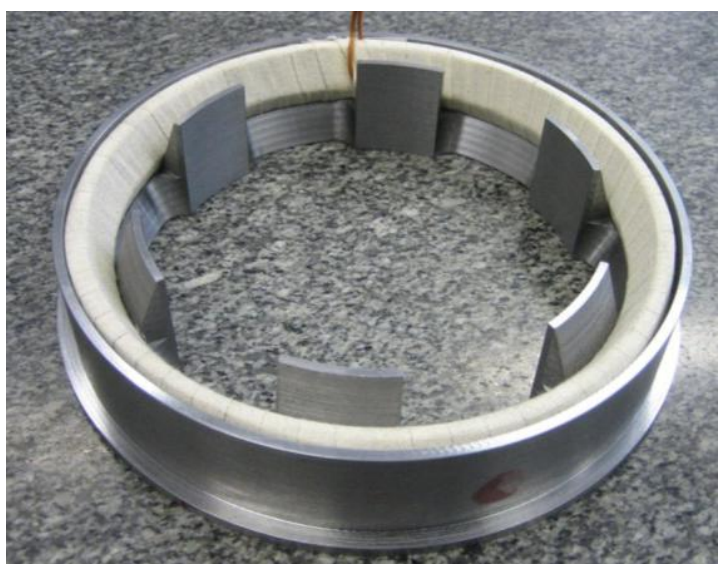

Figure 15: Picture of half the excitation circuit with the winding.

\section{B. Comparative studies of copper losses}

We will compare the copper losses of excitation circuits for the two structures of magnetic excitation circuit.

- Cellular winding (initial solution):

$$
\mathrm{P}_{\text {co } \_c}=\rho \delta_{\mathrm{e}_{-} \mathrm{c}}{ }^{2}\left(\mathrm{~N}_{\mathrm{s}} \mathrm{k}_{\text {be_c }} \mathrm{S}_{\mathrm{be}_{-} \mathrm{c}} \mathrm{L}_{\mathrm{A}}\right)\left(1+\frac{\mathrm{L}_{\mathrm{TB}}}{\mathrm{L}_{\mathrm{A}}}\right)
$$

- Global winding (new solution) :

$$
\mathrm{P}_{\text {co_g }}=\rho \delta_{\mathrm{e}_{-g}}^{2}\left(\mathrm{k}_{\text {be_g }} \mathrm{S}_{\text {be_g }} 2 \pi \mathrm{R}_{\text {be_g_moy }}\right)
$$

With :

$\rho:$ copper resistivity

$\delta_{\mathrm{e}_{-} \mathrm{c}}$ and $\delta_{\mathrm{e}_{-} \mathrm{g}}:$ excitation current density

$\mathrm{N}_{\mathrm{S}}:$ slot number

$\mathrm{S}_{\mathrm{be} \_\mathrm{c}}$ and $\mathrm{S}_{\mathrm{be} \_\mathrm{g}}$ : winding area

$\mathrm{L}_{\mathrm{A}}:$ active length

$\mathrm{L}_{\mathrm{TB}}$ : length of winding heads

$\mathrm{R}_{\text {be_g_moy }}$ : average radius of the global winding

If one accepts that it is the ampere-turns are necessary to the magnetization of the magnetic circuit, we find that:

$$
\mathrm{k}_{\mathrm{be}_{-} \mathrm{c}} \mathrm{S}_{\mathrm{be}_{\mathrm{C}} \mathrm{c}} \delta_{\mathrm{e}_{-} \mathrm{c}}=\mathrm{k}_{\mathrm{be} \_\mathrm{g}} \mathrm{S}_{\mathrm{be} \_\mathrm{g}} \delta_{\mathrm{e}_{-} \mathrm{g}}
$$

If in addition, we compare with the same slot section, the ratio of copper losses is:

$$
\frac{P_{\text {co_c }}}{P_{\text {co_g }}}=\frac{k_{\text {be_c }}}{k_{\text {be_g }}} \frac{\left(N_{S} L_{A}\right)\left(1+\frac{L_{T B}}{L_{A}}\right)}{\left(2 \pi R_{\text {be_g_moy }}\right)}
$$

Numerical application: $\mathrm{k}_{\mathrm{be}_{-} \mathrm{c}}=40 \% ; \mathrm{k}_{\mathrm{be}_{\mathrm{g}}}=70 \%$.

$\mathrm{N}_{\mathrm{S}}=12 ; \mathrm{L}_{\mathrm{A}}=30 \mathrm{~mm} ; \mathrm{L}_{\mathrm{TB}}=27 \mathrm{~mm} ; \mathrm{R}_{\text {be___ } \mathrm{moy}}=52 \mathrm{~mm}$.

$$
\frac{\mathrm{P}_{\mathrm{co}_{\mathrm{C}} \mathrm{c}}}{\mathrm{P}_{\mathrm{co} \_\mathrm{g}}}=3.6
$$

We have verified experimentally, this value, or rather, the magnitude of the value between the copper losses of the excitation circuit for the two types of excitation circuit. For this, we measured, at ambient temperature, the resistance values of the different coils for the two structures:

- Cellular winding : $\mathrm{R}_{\mathrm{exc}}=1.3 \Omega ; \mathrm{R}_{\text {ind }}=0.5 \Omega$

- Global winding : $\mathrm{R}_{\mathrm{exc}}=2.4 \Omega ; \mathrm{R}_{\text {ind }}=0.7 \Omega$

In motor mode, to achieve a mean torque of $5 \mathrm{Nm}$ at 600 rpm, with the initial machine with a winding cell excitation, we found:

$$
\begin{aligned}
& \mathrm{I}_{\text {exc }}=9.8 \mathrm{~A} \text { and } \mathrm{I}_{\text {ind }}=4.7 \mathrm{~A} \\
& \mathrm{P}_{\mathrm{exc}}=125 \mathrm{~W} \text { and } \mathrm{P}_{\text {ind }}=33 \mathrm{~W}
\end{aligned}
$$

For a machine with annular excitation coil, there is a relationship between the armature current and the excitation current.

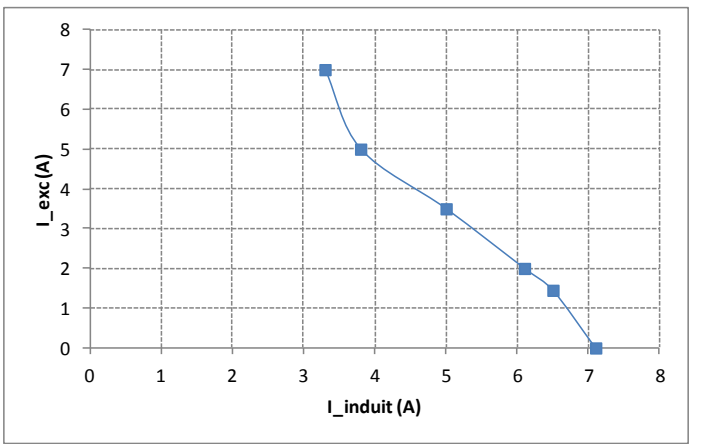

Figure 16: Excitation and armature currents for a constant torque at 5 $\mathrm{Nm}$, for the machine with global winding. 


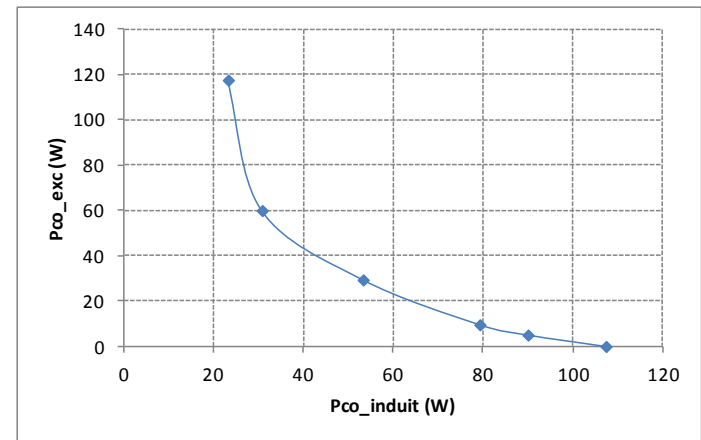

Figure 17: Copper losses for a constant torque at $5 \mathrm{Nm}$, for the machine with global winding.

When comparing the two structures of the excitation circuit, for the same value of torque, we find for the annular excitation coil:

$$
\begin{aligned}
& \mathrm{I}_{\text {exc }}=4.8 \mathrm{~A}_{\text {and }} \mathrm{I}_{\text {ind }}=3.9 \mathrm{~A} \\
& \mathrm{P}_{\mathrm{exc}}=55 \mathrm{~W} \text { and } \mathrm{P}_{\text {ind }}=33 \mathrm{~W}
\end{aligned}
$$

In motor mode, to achieve a mean torque of $8 \mathrm{Nm}$ at 600 rpm, we find for:

- Cellular winding (initial solution):

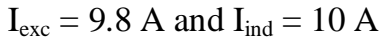

$\mathrm{P}_{\mathrm{exc}}=125 \mathrm{~W}$ and $\mathrm{P}_{\text {ind }}=155 \mathrm{~W}$

- Global winding (new solution) :

$$
\begin{aligned}
& \mathrm{I}_{\text {exc }}=4.9 \mathrm{~A} \text { and } \mathrm{I}_{\text {ind }}=6.9 \mathrm{~A} \\
& \mathrm{P}_{\mathrm{exc}}=57 \mathrm{~W} \text { and } \mathrm{P}_{\text {ind }}=100 \mathrm{~W}
\end{aligned}
$$

We find the expected trend well by the formula (1).

\section{CONCLUSION}

In this paper, we present a new way to achieve the excitation circuit of a synchronous machine flux switching hybrid excitation.

For the study, we performed finite element calculations in 3D. We compared the 3D calculations with experimental tests. Tests in DC generator mode has also been made. This structure of the excitation circuit looks promising in terms of economic copper coil for excitation and in terms of losses. Studies are underway to optimize the shape and constitution of this circuit to minimize the mass of copper used and the copper losses.

\section{REFERENCES}

[1] E. Hoang, M. Lécrivain and M. Gabsi, "A new structure of a switching flux synchrounous polyphased machine with hybrid excitation" in EPE 2007, Aalborg, 2007.

[2] E. Hoang, M. Lécrivain and M. Gabsi, "Flux-switching dual excitation electrical machine". Patent US7868506, 8 march 2007.

[3] R. Owen and Z. Q. Zhu, "Hybrid-Excited FluxSwitching Permanent-Magnet Machines With Iron Flux Bridges". IEEE Transactions on Magnetics, vol. 46, no. 6, pp. 1726-1729, 2010.

[4] B. Gaussens, E. Hoang, P. Manfé, M. Lécrivain, M. Gabsi, 'Improved output power capability of Hybrid
Excited Flux-Switching DC-Alternators: Analysis and experiments". IEEE International Conference on Industrial Technology (ICIT), Athens, Greece, 19-21 March 2012. 